\title{
Globalization and Policy Making; what capabilities and competencies should policy makers obey in globalization? (Market orientation)
}

\author{
Firuze Azizi (Corresponding Author) \\ Economics, $\mathrm{PhD}$ \\ Tarbiat Modares University, Tehran, Iran \\ Tel: +98-22291235, Fax: +98-22291279, Email: fazizi@modares.ac.ir \\ Mohammad Reza Noruzi, EMBA, PhD Student \\ Policy Making in Public Sector \\ Tarbiat Modares University, Tehran, Iran \\ Tell: +98- 412-7238894, Fax: +98-412-7238893 \\ Email: mr.noruzi@modares.ac.ir,mr_norouzi@pnu.ac.ir,mr.noruzi.pnu@gmail.com
}

Received: July 10, 2011 Accepted: August 01, 2011 DOI: 10.5296/jpag.v1i2.747

\begin{abstract}
Globalization has effects on different issues of society especially in policy and policy making. Policy making in this era i.e. the era of globalization is different with other time. It needs policy makers to manage the situation well and look globally instead of thinking just locally. This paper aims to study globalization in general and its effects on policy and policy making.
\end{abstract}

Keywords: Globalization, Society, policy, Effects of globalization on policy making 


\section{Introduction}

Globalization is not a new phenomenon it goes back to the past. When people especially merchants and travelers traveled to the different countries for selling and buying their goods they have exchanged their customs and learned from each other as well. But in this process some instruments like Jet airplanes, cheap telephone service, email, computers, huge oceangoing vessels, instant capital flows, all these have made the globalization process faster than ever (Global Policy Froum, 2011). For more than 20 years scholars from a variety of fields have been engaged in a vigorous debate about a new social phenomenon: globalization (Belk, 1996; Castells, 1996; Featherstone, 1990, 1995; Ger and Belk, 1996; Giddens, 2000; Held et al., 1999; Held and McGrew, 2002; Hirst and Thompson, 1996; Liebes and Katz, 1993; Robertson, 1992; Sklair, 2002; Waters, 1995; Matei, 2006, p.1).

\section{What is globalization?}

Globalization has a lot of definition one is may be defined and realized in many ways. For example, one may speak of economic, social, and cultural globalization (Bornman \& Schoonraad, 2001)

There is a debate on its meaning some says it is process and some say not some says as general phenomena some says as specific others says it is controllable and some says it is compulsory and not controllable.

Therefore the plural ("globalizations") is perhaps more accurate (Braman \& Statan, 2000). Teitel (2005) defines (economic) globalization as “. . the phenomenon of increased integration of the world economy as evidenced by the growth of international trade and factor mobility.” (p. 445). After a while, he notes “As far as technology, and the fruits in general of research and development, globalization has not made much of a difference, at least so far, to the developing countries”' (p. 458; Landis, 2008, p.338).

\section{Pro-globalization and Anti-Globalization, the two perspectives in globalization}

In general According to Irani and Noruzi (2011), there are two general mainstreams about this phenomenon as comes in the following briefly:

1. Pro- globalization, this is a belief about those who believe that; globalization will bring lots of advantages for them and i.e. advantages of globalization are more in comparison with its disadvantages. And globalization will produce efficient competitive markets.

2. Anti-globalization, Other who says this will have not worked well in. And those countries have not capability to compete in this era within the increased competitive pressure that will be brought about by allowing their economies to be more connected to the rest of the world (investor word, 2005; Noruzi \& Irani, 2011). 


\section{Globalization's effects on our policies}

Definitely globalization has effects on our international law, national and international and cross national policies. We cannot omit the role of globalization in the area of policy and policy making. Traditionally politics has been undertaken within national political systems. National governments have been ultimately responsible for maintaining the security and economic welfare of their citizens, as well as the protection of human rights and the environment within their borders.

Policies are interrelated and effect on each other. In nowadays policies change globalization challenges have been transferred policies from national to upper levels. With global ecological changes, an ever more integrated global economy, and other global trends, political activity increasingly takes place at the global level. It is definitely true because countries should adopt themselves with the globalization phenomena (Globalization, 2005: Irani \& Noruzi, 2011).

Previously our policies were limited to the very limit sphere for example rural areas, cities and maximally in national. But now one country cannot live alone and should communicate with the other ones and this needs accepting global agendas. So our policies should change from national to international ones. During this process the global social justice movement, itself a product of globalization and intense political disputes will continue over globalization's meaning and its future direction (Global Policy Froum, 2011).

\section{Important factors for making effective globalization - policy making linkage}

Effective factors in the process of globalization especially in the last two decades are, technological and electronically development like intranet, internet, mobile and telephone, satellite, cellular phones (investor word, 2005).

Making a tight fastening between globalization and policy and policy making will cause organizations to be effective in this era.

Some recommendations come in the following:

- Training global managers

- Training global staff and employees who are engaged in policy making

- Holding some workshops to learn the advantages of having global policies

- Holding some conferences in national and international biases

- Subscribing for journals related to policy and policy making so that our policy makers to be updated with the latest NEWS and information about globalization and policy making in that.

\section{Globalization's Effects on companies marketing policies}

Globalization will develop huge and multinational markets and this will increase the selling rate in countries market. It causes companies to expand their boarders from national to 
international. It will increases the cash follow for example international trade in manufactured goods has increased more than 100 times (from $\$ 95$ billion to $\$ 12$ trillion) since 1955(BBC NEWS, 2007). China's trade with Africa rose sevenfold during 2000-07 alone (Times Online, 2008; Politzer, 2008).

So companies should try to use international and multinational marketing standards and use policies in the international levels and marketing policy makers should develop their capabilities to international competencies.

Globalization also causes policy makers to think about one of the most important factor in the market called Market Intelligence, MI. Market Intelligence (MI) is the information relevant to a company's markets gathered and analyzed specifically for the purpose of accurate and confident decision-making in determining market opportunity, market penetration strategy, and market development metrics. Market intelligence is necessary when entering a foreign market (Noruzi \& Irani, 2011, p.57).

\section{Results and Conclusions}

Globalization typically refers to the process by which different economies and societies become more closely integrated, and this will causes a lot of consequences on different aspects of globalized markets (Nilson, 2010, p.1191).

After a brief look on the globalization and some brief review on the effects of globalization on policy and policy making especially in different faces of policy like in marketing policy. We can conclude that if a country wants to enter to globalization process should try to use policies effectively (Globalization, 2005).

Multinational corporations manufacture products in many countries and sell to consumers around the world. Money, technology and raw materials move ever more swiftly across national borders (Global Policy Forum, 2011).

Civil society organizations act globally by forming alliances with organizations in other countries, using global communications systems, and lobbying international organizations and other actors directly, instead of working through their national governments (Globalization, 2005).

\section{The last one, what should policy makers do to be close to the market?}

There are some fundamental steps for policy makers to do to make fill the gap in the globalization. They need to fully understand them, including the roles that the competitors and customers play there.

- Make globally the Market and customer orientation

- Do the better ones with fast identification of new global opportunities - e.g. identify new trends because globalization definitely will emerge new opportunities and trends

- Act fast and Early warning of competitor moves

- Minimizing investment risks - detect threats and trends in the mean time 
- A good policy maker should obey from a global government

- Know the orientations of all customers if not all the most one is preferred- inherit intensified customer market view

- A good policy maker should obey from a global market as well

- Choosing the good and suitable market and selecting the good ones then positioning

- A global policy maker should know the cost benefit Analysis well and obey from it (Noruzi \& Irani, 2011)

\section{References}

BBC News, (2007), "Globalization shakes the world". BBC News. January 21, 2007.

Belk, R.W., 1996. Hyperreality and globalization: culture in the age of Ronald McDonald. Journal of International Consumer Marketing 8 (3-4), 23-37.

Bornman, E., \& Schoonraad, N. (2001). The many faces of globalization. Mousaion, 19(1), 83-114.

Braman, S., \& Statan, C. V. (2000). Globalization and culture. Study guide for Unit 12 of the Postgraduate Diploma in Telecommunications and Information Policy.

Irani, Farhad Nezhad Haj Ali, Mohammad Reza Noruzi, Globalization and Challenges; what are the globalization's contemporary issues? International Journal of Humanities and Social Science (IJHSS), Vol. 1 No. 6; June2011, ISSN :- 2220-8488, pp. 216-218

Featherstone, M., 1990. Global Culture: Nationalism, Globalization, and Modernity. Sage Publications, London.

Featherstone, M., 1995. Undoing Culture: Globalization, Postmodernism and Identity. Sage Publications, London.

Ger, G., Belk, R.W., 1996. I’d like to buy the world a coke: consumptions capes of the "less affluent world”. Journal of Consumer Policy 19, 271-304.

Rahimi, Gholam Reza, Mohammad Reza Noruzi, How Globalization Phenomena Manage Its Related Issues and Affairs? International Journal of Humanities and Social Science (IJHSS), ISSN :- 2220-8488, Vol. 1 No. 6; June2011 , pp. 184-187

Global Policy Forum, (2011), available online at:

Globalization, 2005, globalization, available online at: www. Globalization/globalization.html

Globalization, 2005, globalization, available online at: www. Globalization/globalization-of-politics.html http://www.globalpolicy.org/globalization/defining-globalization.html 
Investor word, (2005), Globalization, available online at:

http://www.investorwords.com/2182/globalization.html

Irani, Farhad Nezhad Haj Ali, Mohammad Reza Noruzi, 2011, Globalization and Effects; A study on the effects of globalization in the society, Interdiciplinary journal of contemporary research in business, May edition,

Landis, Dan, 2008, Globalization, migration into urban centers, and cross-cultural training, International Journal of Intercultural Relations, 32 (2008) 337-348

Liebes, T., 2003. American Dreams, Hebrew Subtitles: Globalization from the Receiving End. Hampton Press, Cresskill, NJ.

Liebes, T., Katz, E., 1993. The Export of Meaning: Cross-cultural Readings of Dallas, second ed. Polity Press, Cambridge.

Matei, S.A. I (2006), Globalization and heterogenization: Cultural and civilizational clustering in telecommunicative space (1989-1999) Telematics and Informatics 23 (2006) 316-331

Nilson, Theresse, (2010), Good for Living? On the Relationship between Globalization and Life Expectancy, World Development Vol. 38, No. 9, pp. 1191-1203, 2010

Noruzi, Mohammad Reza, Farhad Nezhad Haj Ali Irani, (2011) MARKET INTELLIGENCE AND ITS APPLICATIONS IN ACCOUNTING AND ACCOUNT MANAGEMENT, Economics and Finance Review Vol. 1(3) pp. 55 - 58, May, 2011 ISSN: 2047 - 0401

Politzer, Malia, (2008) "China and Africa: Stronger Economic Ties Mean More Migration". By Malia Politzer, Migration Information Source. August 2008.

Pretoria: UNISA.

Robertson, R., 1992. Globalization: Social Theory and Global Culture. Sage, London.

Sklair, L., 2002. Globalization: Capitalism and Its Alternatives, third ed. Oxford University Press, Oxford, UK.

Times Online, (2008) "Africa, China's new frontier". Times Online. February 10, 2008.

Waters, M., 1995. Globalization. Routledge, London. 